\title{
What is the Legacy of Austrian Academic Liberalism?
}

\author{
Veronika Hofer and Michael Stöltzner
}

In her book Vienna in the Age of Uncertainty: Science, Liberalism, and Private Life, Deborah Coen 2007 portrays one of the most influential academic dynasties of Habsburg Austria over the course of three generations, starting with the philosopher and educational reformer Franz Exner (1802-1853) and extending into the 1940s. "With their hands in projects spanning science, politics, and the arts, the Exner family is an ideal guide for a tour of Vienna at the turn of the twentieth century" (Coen 2007: 3), and a paradigmatic case for Austrian liberalism as it developed over eight decades. With this family Coen has without a doubt discovered a treasure chest for the history of science, the history of ideas, and European social history. She utilizes it to produce a contribution to the history of Austrian science and academic liberalism in Habsburg lands, seminal notably because it eschews the trend to simply subsume Austrian research under German traditions and perspectives, inherent in several histories of European science. In our essay, we will first review Coen's argument, and then pass on to discuss a contrasting narrative about the legacy of Austrian academic liberalism in the twentieth century, as outlined in Malachi Hacohen's 2009 long essay review of Coen's book.

Even though the second generation of the Exners played a leading role at the University of Vienna, where the jurist Adolf (1841-1894) and the experimental physicist Franz Serafin (1849-1926) ascended to rectorship, and where the physiologist Sigmund (1846-1926) oversaw the reorganization of the Medical Faculty, Coen identifies the family's defining location as a group of farmhouses at Brunnwinkl in Upper Austria, bought by their sister Marie von Frisch (1844-1925). There the whole family - including Karl (1886-1915), a professor of mathematical physics at Innsbruck who is largely absent from Coen's narrative - assembled for their annual Sommerfrische. For Coen, 
Brunnwinkl represents more than a summer retreat, functioning simultaneously as the place where the Exner siblings - who because of the untimely deaths of their parents had been raised separately by their father's friends reinvented their family and as "an integral part of their self-fashioning as liberals." (Coen 2007: 89) It also became an experiment in both the liberal education of the third generation and the development of a science that leaves the laboratory to go out 'into the open' - ranging from observations about how insects perceive the colors of flowers to the measurement of atmospheric electricity.

In the Exner family's historical construction of memory, Brunnwinkl worked in two directions - a fact, which we want to stress more explicitly than Coen does. In Emilie's privately printed booklet from 1908, she interprets Brunnwinkl - along with the scientific achievements and social prestige that it helped her family foster - as the fulfillment of a utopian dream of Franz Exner, who died young as the first of his family. At the end of the Second World War, Alfred's son Franz Exner (1881-1947) looked back into a distant past of the Exnerei (1944); a world of which even the remains were being shattered. Only the first memory, albeit somewhat nostalgic in spirit by virtue of its conflation of family tradition and liberal modernity, points towards a promising future. The latter merely comes across as a family album remembering past achievements.

Coen's book challenges Carl Schorske's 1980 description of Vienna's finde-siècle years as a crisis of rationalism and liberalism. According to Schorske, science and reason gave way to new aesthetics dominated by subjectivity. Instead of fractures and retreat, as Schorske has it, the Exner family, in Coen's reconstruction, testifies to the enduring continuities between "science and aesthetics, reason and subjectivity" (Coen 2007: 2). By rejecting determinism in science and history, and relying instead upon probabilistic reasoning, the liberals were able "to define rationality in such a way as to discredit at once the absolute claims of religion while justifying their claim to knowledge that transcended a narrowly class- or nation-based perspective." (Ibid.: 12) The fin-de-siècle decline of liberalism could thus be averted, at least for a while. Coen's continuist narrative about liberalism and rationality, like the books of Pieter Judson 1996 and John W. Boyer 1995, reveals particular limitations of Schorske's picture while complementing it in important respects - not least by adopting a new methodological approach that combines family history, the history of scientific concepts and a deeper look at experimental cultures.

To better understand Coen's project, it is helpful to contrast the third Franz Exner's construction of memory of 1944 with Stefan Zweig's (18811942) autobiography Die Welt von Gestern. (1942) While Zweig characterized the 'World of Yesterday' by insurance companies and administrative statistics, a technological regime against which his generation of young literati rebelled, 
the Exners anchored probability in what they took to be a new type of natural law; in doing so strove to maintain the Humboldtian bond between science and aesthetics which for the generation of Zweig had become brittle and an expression of a stale world view. Zweig wrote his autobiography in exile, and it was posthumously published after his tragic suicide. In the 1930s and 1940s, the fates of Coen's Exners and Schorske's primarily Jewish intellectuals, among them Zweig, turned out quite differently.

Schorske famously used Gustav Klimt's mural "Philosophie" to embody his narrative. The Exner brothers were in the group of professors, who finally prevented that the project was completed in the Philosophical Faculty of the University of Vienna. Where they "had expected to find an allegory of enlightenment, they saw no more than the nightmare of a troubled mind." (Coen 2007: 203) Instead they called for a renewed Enlightenment as a way of circumventing the fractures between the emotional and the rational brought about by the modern world. Following the manifold "ways in which the Exner family generated memories and forged continuity" (ibid.: 25) and analyzing their scientific achievements, Coen's book may also be viewed as a kind of painting in the Enlightenment style, depicting the assembled Exners as scientists, each of them holding or pointing to his most important discovery, and all set against the characteristic landscape of Brunnwinkl. But after 1900 rationality could no longer be rooted in the Laplacian deterministic system that overcame the intellectual hold of the ancien régime. Instead it was emerging from both probability - as the new universal measure capable of taming the uncertainties of the modern world - and liberal science - for which determinism now smacked of traditional or novel claims to unconditional authority. Therefore a lot depends on the proper historical understanding of the 'probable'.

[Coen] do[es] not claim that the meaning of the 'probable' was constant or uniform throughout [the eight decades from the 1850s to the 1930s]. Probability in the Exner circle was variously an epistemological standard, a tool for quantifying the bounds of physical variability, and a model of mental function. It began as a reflection of human ignorance and became a mirror of the fundamental randomness of the physical world. [...] Whether they dealt with physical, psychological, or social phenomena, they believed that the world was too complex to admit of deterministic laws. (Ibid.: 30-31)

Coen is wise to build her narrative on a variety of characteristics. Yet in our view, the semantic field of the 'probable' - or rather of the German 'wahrscheinlich' - was even more inclusive than Coen thinks and contained historical developments that occurred on different time-scales and interacted in a variety of ways. An archeology of the 'probable' in the context of the Exners would, to our mind, identify the following meanings. The list below that we present roughly in chronological order does not pretend to be exhaustive. It excludes themes not broadly discussed by Coen, including above all evolution 
and Darwinism; areas where in those days the fight between mechanism and probabilism was as heated as it was in physics.

(i) Authority: Ian Hacking 1975 has linked the historical origins of probability to authority and evidence. On this time-scale reaching back to the Middle Ages the liberals waged their battles in favor of the 'probable' social order and against any kind of scholasticism, dogmatism or absolutism.

(ii) Verisimilitude: The demand for a probable story goes back at least as far as Enlightenment poetics. Taken literally, the German term 'wahrscheinlich' (probable) means that the subject it refers to seems to be true. Accordingly, where fin-de-siècle arts abandoned the probable for the merely possible - as the Exners felt Klimt had - they destroyed the bond between science, aesthetics, and education woven, after different fashions, in both the Enlightenment and Alexander von Humboldt's Cosmos, a book the Exners held dear.

(iii) Loss of certainty: In the second half of the nineteenth century, after the heyday of German idealism, empiricists and liberals - among them Franz Exner - were not alone in abandoning the quest for ultimate, metaphysically unassailable truths; Kantians like Hermann von Helmholtz also felt the Wahrheitsgewissheitsverlust (loss of certainty) - as Gregor Schiemann 1997 aptly put it in.

(iv) Causality and complexity: As Coen rightly observes, the problem of causality became all the more pressing for the second generation Exners because new discoveries and technological progress allowed science to address meaningfully complex real-world problems. This required scientists to scrutinize measurement errors and attempt to lower the effects of manifold disturbances. Science had to go "into the open", not only - as Coen has it - into the Alps, but also into the turbine house of an artificial lake.

(v) Probabilistic physics: The specific idea of a probabilistic physics, unlike the renewed empiricism (iii) and statistical error analysis (iv), dates back only to the works of Ludwig Boltzmann and James C. Maxwell in the 1880s. Its emergence is part of a process that Erwin Hiebert 2000 has aptly called the "Austrian revolt in classical mechanics". It is a pity that Coen does not mention Hiebert's paper. Not least because his claim that in this revolt "probability and chance, as generated from within the social and humanistic disciplines, came to inspire and motivate investigators in the physical sciences to take a deeper look" (Hiebert 2000: 7), provides either a partial aspect of, or an outlook competing with the ubiquity and simultaneity of liberal probability Coen diagnoses.

(vi) Indeterminism: Only against the backdrop of a successful probabilistic science (v) was it at all possible to contemplate the idea that chance 
formed the basis of all natural laws and that statistical laws were not merely transitory. This indeterminist outlook, which dominated Franz Serafin's 1908 rectorial address, came as the culmination of his circle's successful research into what would later be called the physics of fluctuations. All of his students advocated the feasibility of an indeterminist description of nature long before the advent of quantum mechanics. Afterwards, they tirelessly stressed Exner's priority in this view.

(vii) Interpretation of probability and hilltop liberalism: Exner's indeterminism took the relative frequency interpretation to be the only means of obtaining an objective conception of probability. The question of certainty and uncertainty, at least at its deepest level, was no longer tied to subjective knowledge and beliefs. By treating society as a probabilistic process, Franz Serafin could even take an agnostic stance regarding the details of each individual's motivations as long as the observable regularities of society as a whole came out right. For an academic liberal, this was a comfortable stand on the hilltop. But it went straight against the methodological approach taken by the Austrian School of Economics, which relied on individual utilities and preference orders; they too were liberals even though they are largely absent from Coen's story.

Coen's book is particularly strong where the author embarks on detailed investigations. This is the case in her account of how the women's role change in the liberal family over two generations, where she discusses Marie von Frisch and Sigmund's wife Emilie (1847-1909), who embedded the ideal of Bildung into family life without professional ambitions, and the more independently minded artist-daughters Nora (1879-1915) and Hilde (1880-1922). Moreover Coen details two generations of Exners in their deep involvement with various educational reforms in Habsburg lands, tracing them as they steered the increasingly narrow path of Liberalism between Catholicism and the cry for radical social reform.

No other field illustrates the Exners' interdisciplinary approach and unique understanding of the relationship between science and aesthetics better than the theory of color. Franz Serafin and the members of his circle were engaged with the problem of finding a suitable metric and methods of measurement, while Sigmund worked on the physiology of perception. Together, they analyzed the beauty of colors. At Brunnwinkl, Sigmund and future Nobel Laureate Karl von Frisch studied the co-evolution of the perception of color in insects and the colors of plants. Franz Serafin defined the concept of the 'normal eye' in order to get a better empirical understanding of the arts, only to see members of his own circle (among them Erwin Schrödinger), arguing that the idea was scientifically untenable. Coen rightly situates these investigations in the tradition of empirical art research 
prevalent in Habsburg lands. This body of scientific knowledge about color contributed to the formation of a distinctively Austrian style in the arts and crafts.

Equally groundbreaking is Coen's analysis of how Franz Serafin's circle came to understand fluctuations as phenomena in their own right, and not simply as indicators of an undiscovered natural law. She emphasizes the importance of the work in atmospheric electricity in directing the naturalist's attention away from idealized laboratory experiments and out into the open, to a complex of changing phenomena. The same bottom-up empiricism proved fruitful in Egon von Schweidler's discovery of radioactive fluctuations as well as Marian von Smoluchowski's solution to the problem of Brownian motion. Both Sigmund in 1867 and his son Felix Exner in 1900 had made important contributions to the latter field in the early years of their careers when they excelled in achieving experimental precision. This, however, was no science suited for Brunnwinkl, requiring instead the laboratories of Ernst von Brücke and Franz Serafin for its successful performance.

Notwithstanding their prodigious scientific achievements and towering influence on Austrian science, the history of the Exners is also marked by fractures and shorn identities to a greater extent than Coen would like to admit. A case in point is Coen's discussion of Franz Serafin's correspondence with Houston Stewart Chamberlain, where his attempt to agree with Chamberlain's cultural diagnosis while remaining loyal to scientific fact was bluntly rebuffed. A similar sense of disjunction is also apparent in his friendly criticism of Oswald Spengler's Untergang des Abendlandes (Hiebert 2000, Stöltzner 2002). Finally and more importantly than Coen argues, Franz Serafin's cultural theory of 1923 reveals, to our mind, a characteristic dialectic between liberal theory and life: As the increasing exchange of cultures following the second law of thermodynamics engenders modern civilization, it works simultaneously to threaten Brunnwinkl in the form of increased tourism.

This is not, in our opinion, the only relevant tension in the world of the late Habsburg academic liberals, who reacted in differing ways to developments following their own theoretical conceptions once these intruded into their own private sphere. The Exners' confidence that the 'probable' would tame the uncertainty ('Unsicherheit') of the modern world was also rooted in personal security ('Sicherheit'). Members of the largest academic dynasty of Habsburg Austria, and all full or corresponding members of the Academy of Sciences which in those days was at the height of its international recognition - the Exners detested the rise of Karl Lueger's catholic nationalism, prevalent among the Kleinbürger (petty bourgeoisie), and remained critical about the social democratic call for equality. None of the fin-de-siècle controversies threatened the family's material existence. Many of the urban intellectuals and artists featuring in Schorske's story, however, were directly affected by the economic pressures stemming from the social changes and national conflicts of the time. Other liberals, such as 
the industrialists, the economists of the Austrian School, and the bureaucracy in the provinces of the extended Habsburg Empire, faced the problem of how to understand and influence an increasingly complex social reality.

There is no doubt, however, that the Exners were affected by the drastic changes in the aftermath of the fall of the monarchy. On the occasion of their retirement immediately following the war, Franz Serafin and Sigmund could look back on a long list of successful disciples and new institutions they had fathered, but the dominance of academic liberalism had disappeared. In the increasingly violent conflicts between the Catholic right, the Social Democrats and the German nationals, the Exners lost any viable political base. No longer credible as a model, Brunnwinkl became only a retreat. And while the high quality of Austrian science remained undiminished - with some noteworthy exceptions - it was no longer the science of Brunnwinkl.

With the deaths of Marie, Sigmund, and Franz Serafin in 1925 and 1926, the second generation of Exners came to an end. Even before this, four of the 13 Exners of the third generation had already passed away. In 1927, the Viennese police fired into a large crowd of demonstrators that had set fire to the Justizpalast, killing 89 people; this event marked the beginning of the end of the short-lived first Austrian republic. During the years 1926 and 1927, Schrödinger developed the theory of wave mechanics, ultimately leading to a vindication of Viennese probabilism - at least in the eyes of most physicists. But this shift towards abstract theory left quite a few of Franz Serafin's students behind. Similarly, while the early study of radioactive materials took the form of typical tabletop experiments where the main instrument, the electroscope, could be carried into the Sommerfrische to measure atmospheric electricity, by the mid 1920s the field had turned into big laboratory science, making it difficult for the Viennese to keep up with richer institutions around the world.

Coen's book could very well have ended at this point, but the family narrative pushes her further to a "Conclusion" that opens a Pandora's box of new and urgent questions. Among the few remaining Exners of the third generation, three entertained sympathies for the Nazi regime. Attempting to account for this fact, Coen explains that " $t$ ] o expect that each generation of the Exner family would conform to the ideas of their parents underestimates the complexity of Central European history and of family dynamics." (Coen 2007: 345) Fair enough - but was this history not quite complex already and has Coen not assembled two generations of Exners into a narrative that employs family history to challenge the complex Schorskian paradigm? From a methodological perspective, by abandoning the coherence of the Exner narrative uniting family, science and politics, Coen effectively jettisons the very foundations of her claim to have found an alternative to Schorske's story of resignation and individuation. If the Exners can no longer be considered the leading dynasty of academic liberalism, becoming instead singular individuals 
cultivating family memories and reacting in different fashions to political and social turmoil, they are reduced to mere actors, atomized within a broader history that still remains to be told, namely, why some liberals entertained Nazi sympathies while others sided with the Socialists.

With regard to this history, Coen limits herself to the level of scientific ideas and educational programs. She briefly examines the jurist Franz Exner's (1881-1947) use of racial stereotypes in his criminal biology and sketches the diverging metamorphoses of some liberal ideas, but does so without elaborating the fate of the corresponding political agenda. She contrasts socialist educators like Otto Neurath who integrated Austria's legacy of probabilistic liberalism into a new political context with the Austrian School of Economics that divorced it from its pedagogical agenda. Both groups were forced into emigration. The same fate awaited Karl Popper, whose "alignment of science and democracy against the intimate sphere undermined the authority of the Bildungsbürger elites." (Coen 2007: 352) However, as Coen reads it, even Popper's Open Society (1945) excepts "some lucky family groups" (ibid.: 352, quoting Popper) from the general rule that rationality could not take root in the private sphere: in his long critical review of Coen's book, Malachi Hacohen 2009, who also authored a justly praised study of Popper's formative years in Vienna (Hacohen 2000), finds fault with her conclusion and develops a different reading of the legacy of Austrian liberals that, following Popper's rule, emphasizes the public and democratic features of science rather than the Exnerian exception. He claims that "[l]ike Schorske, Coen leaves the major riddle of Austrian liberalism, its rapid devolution into German ethnonationalism, unresolved." (Hacohen 2009: 375) Coen, Hacohen complains, "seems genuinely perplexed to find the third generation of Exners turning Nazi" (ibid.: 386) and "treats the young Exners' shift from liberalism to ethnonationalism as if it were anomalous, whereas it was typical." (ibid.: 387) To his mind, "the children tweaked the parent's liberalism to convey nationalism and racism" (ibid.: 389), integrating Brunnwinkl into a Heimat discourse with anti-Semitic overtones. Did the Exners simply become typical? The problem is that it is unclear whether or not scientists in academia would be considered 'special' compared to jurists, artists and the like. Coen's book suggests that until at least the 1920s they were.

Hacohen rightly diagnoses "strong aristocratic dimensions" (ibid.: 381) within Austrian liberalism. Lacking the political powers of the old aristocracy, the Academy of Sciences constituted the Exner's sphere of prestige and influence, a fact that, in our opinion, both Coen and Hacohen underemphasize. For instance, when Hacohen observes that Coen "wants Brunnwinkl to be, it seems, the site for the production of liberal science" (ibid.: 380) by which she "mount[s] a challenge to science's public character," (ibid.) one should not forget that the fruits of all their research were brought into the Sitzungsberichte of the Academy of Science. The sheer number of the "Beiträge zur Kenntnis 
der atmosphärischen Elektrizität" (Contributions to atmospheric electricity) heaped up by the Exner circle in the Sitzungsberichte was legion and the tradition continued long after Franz Serafin's death, most importantly through von Schweidler. The science of the academic aristocrats including Brunnwinkl's private science went public among the Exners' peers without being fully democratic.

Firmly embedded in Academy and University, the Exners were less affected by political turmoil than artists and public intellectuals were. As Hacohen observes, "Austria did not develop a liberal political culture until well into the post-World War II era. Liberal scientific culture fared better." (Hacohen 2009: 392). Things changed when the rise of Austrofascism in 1934 and the Anschluss in 1938 forced many scientists out of the University and into emigration. Coen "shows the Exners' greatest theoretical and scientific accomplishments coming at the height of crisis, when their critics had already consigned liberal culture to oblivion." (Ibid.: 382) Yet in doing so, she merely "recharts the fault line Schorske has drawn between liberalism and modernism. The chasm between modern science and modern art remains open." (Ibid.: 385)

Hacohen's own case about Austrian liberalism develops not from a closer examination of the Exners of the third generation, but from the main concept of Coen's narrative, probability. "The liberals vied for probability precisely because it contained the chaos they saw emergent in modernist art and made liberalism indispensable." (Ibid.: 384)

None suggested, as Popper would, that knowledge, or scientific laws, remained forever conjectural. [...] None endorsed, as Popper would, [...] the idea that there were no historical laws, not even probabilistic ones. Such radicalism could undermine liberal authority. The universe had to be lawful so that $[\ldots]$ the liberals could expertly manage risk. (ibid.)

By this contrast, Hacohen at bottom ushers Coen's Exners back into the traditional cohort of liberals whose paternalist attitude stands in a marked contrast to Popper's Open Society.

With reference to his probabilistic cultural theory, Franz Serafin (1923: 281) indeed claims that in science, "due to the objective truth of its results, [...] there is no 'way back', but only a necessarily arising expansion." For the Exners, science thus survives the decline of individual cultures and the shift to worldwide civilization. Hacohen's conception of liberalism's longue durée draws more radical lessons from its cultural demise, emphasizing the discontinuities and increasing internationalization brought about by the emigration of European intellectuals. "Popper's critical rationalism appears as the radicalization of a long Austrian pedigree of uncertainty." (Hacohen 2009: 394) In this way, uncertainty became a central tenet of liberal science, but in the form of non-foundationism and liberal democracy. Hacohen concludes that by 
[a]nchoring liberal science in domestic life and ignoring the cosmopolitan character of Popper's democratic public, [... ] [Coen] undercuts the major links tying liberalism and democracy, nineteenth- and twentieth-century philosophy of science-their progressivism and internationalism. This diminishes the Exners' legacy.[ ....] She has no way of reclaiming the liberal legacy from the Nazi Exners and falls back on their nostalgia for the old order. (Ibid.: 393-394)

Reclaiming the liberal idea by Popperian means, however, comes at a philosophical price that had negative impacts on the interactions between historians and philosophers of science. It requires explicit criteria that demarcate science from other activities, and normative criteria for determining good science. Kuhn and Feyerabend attacked both requirements in their classic debates with Popper and Lakatos during the 1960s and 1970s. Lakatos 1978 rephrased the problem as an alternative: rejection of any binding demarcation criteria yields into either skepticism or elitism. Although at first glance the liberal alpine science of the Exners seems to fall squarely into the elitism category, one has to bear in mind that their aristocratic peers in the Academy of Science expected good science based on a sound methodology.

Moreover, some philosophical ideas for which Popper has become famous stand in contrast to the broader Austrian tradition, including the Exners. First, Popper abandoned the relative frequency interpretation of probability - which after 1900 had held sway with a growing number of scientists - in favor of a propensity interpretation according to which a system has an inherent tendency to yield a certain outcome. Adopting Coen's wider sense of probability, we find that Konrad Lorenz - Popper's comrade in arms in matters of evolutionary epistemology - relied on Karl Bühler's psychology, in which the concept of a Spielraum (range) of alternatives plays a crucial role (Hofer 2001). Bühler's teacher Johannes von Kries used this concept as the basis for an interpretation of probability that, at the turn of the century, rivaled the relative frequency interpretation preferred by the Exners. Second, Popper's notorious crusade against any application of inductive methods derails the Exners' bottom-up empiricism, effectively downgrading the greater part of Brunnwinkl science to modestly bold conjectures made on vacation and non-severe testing in the open.

In conclusion, Coen challenges Schorske's grand narrative of crisis by developing a continuist story of a dynasty of Viennese scientists. But unlike mathematical theorems, grand narratives cannot be refuted by counterexample. They can only be amended or replaced. To our mind, Coen amends Schorske rather than replacing him, but without finally showing that the Exners were more than just a 'tour guide' for the liberalism of the declining Habsburg Empire. Hacohen tries to supplant Schorske's narrative by outlining a different one that emerges from what he rightly identifies as a central problem of Austrian liberalism - and which is conspicuously absent from Coen's book - namely, its devolution into nationalism. Their historiographical 
perspectives could not be more different. Coen begins with nineteenth century academic liberalism and shows that its demise occurred later relative to most aspects of Habsburg culture and goes on to identify probability as its bequest to modernity - at least in some parts of its semantic field. Hacohen's account sets out with a post-1945 ideal of democratic science and arguably takes the Viennese liberal Popper as its main voice. Both perspectives complement each other, but they have their inherent limitations. It is the merit of both authors to have once again put the legacy of Austrian liberalism on the historians' agenda.

\section{Acknowledgments}

The authors are greatly indebted to Hollis Beach and the editors of NTM for manifold suggestions on how to improve clarity and style of the present paper.

\section{Literature}

Boyer, John, 1995. Culture and Political Crisis in Vienna: Christian Socialism in Power, 1897-1918. Chicago: Chicago University Press.

Coen, Deborah R., 2007. Vienna in the Age of Uncertainty. Science, Liberalism, and Private Life. Chicago/London: The University of Chicago Press.

Exner, Emilie, 1906. Der Brunnwinkl. Vienna, private printing.

Exner, Franz Serafin, 1909. Über Gesetze in Naturwissenschaft und Humanistik. Wien/Leipzig: Alfred Hölder.

Exner, Franz Serafin, 1923. Vom Chaos zur Gegenwart, unpublished mimeographed typescript.

Exner, Franz, 1944. Einiges über die Exnerei. Staltach, private printing.

Hacohen, Malachi, 2000. Karl Popper-The Formative Years, 1902-1945: Politics and Philosophy in Interwar Vienna. Cambridge/New York: Cambridge University Press.

Hacohen, Malachi, 2009. The Culture of Viennese Science and the Riddle of Austrian Liberalism, Modern Intellectual History, 6, 2, 369-396.

Judson, Pieter, 1996. Exclusive Revolutionaries. Liberal Politics, Social Experience, and National Identity in the Austrian Empire, 1848-1914. Ann Arbour, MI: University of Michigan Press.

Hacking, Ian, 1975. The Emergence of Probability. A Philosophical Study of Early Ideas about Probability, Induction and Statistical Inference Cambridge: Cambridge University Press.

Hiebert, Erwin N., 2000. Common Frontiers of the Exact Sciences and the Humanities, Physics in Perspective, 2, 6-29.

Hofer, Veronika, 2001. Konrad Lorenz als Schüler von Karl Bühler. Diskussion der neu entdeckten Quellen zu den persönlichen und inhaltlichen Positionen zwischen Karl Bühler, Konrad Lorenz und Egon Brunswik, Zeitgeschichte, 28, 135-159.

Lakatos, Imre, 1978. The Problem of Appraising Scientific Theories: Three Approaches. In: idem: Mathematics, science and epistemology [=Philosophical Papers, 2], Cambridge: Cambridge University Press, 107-120.

Popper, Karl R., 1945. The Open Society and Its Enemies. 2 vols. London: Routledge.

Schiemann, Gregor, 1997. Wahrheitsgewissheitsverlust: Hermann von Helmholtz'Mechanismus im Anbruch der Moderne. Darmstadt: Wissenschaftliche Buchgesellschaft [abbreviated English translation: Hermann von Helmholtz's Mechanism: The Loss of Certainty, A Study on the Transition from Classical to Modern Philosophy of Nature. Dordrecht: Springer 2009].

Schorske, Carl, 1980. Fin-de-Siècle Vienna: Politics and Culture. New York: A. Knopf. 
Stöltzner, Michael, 2002. Franz Serafin Exner's Indeterminist Theory of Culture, Physics in Perspective, 4, 267-319.

Zweig, Stefan, 1942. Die Welt von Gestern. Erinnerungen eines Europäers. Stockholm: BermannFischer [English translation: The World of Yesterday. An Autobiography. New York: Viking Press 1943].

Veronika Hofer

Department for History of Medicine

Medical University of Vienna

Währinger Strasse 25

1090 Wien

Austria

E-Mail: Veronika.Hofer@meduniwien.ac.at

Michael Stöltzner

Department of Philosophy

University of South Carolina

Columbia, SC 29208

USA

E-Mail: stoeltzn@sc.edu 